\title{
SPATIAL DEVELOPMENT OF THE CARPATHIAN REGION IN THE CONTEX OF EUROPEAN INTEGRATION PROCESSES
}

\author{
Natalya TSENKLER ${ }^{1}$, \\ Uzhgorod Trade and Economic Institute of Kyiv National Trade and Economic University, Ukraine
}

\begin{abstract}
The purpose of this publication is valuation of theoretical subsoil and prospective of spatial development of the Carpathian region in the context of deepening of European integration processes. Methodology. The monographic method, comparison, analysis and synthesis, mapping method were used in the study. Results. The theoretical bases and ways of spatial development of the Carpathian region in the context of European integration processes are discussed in the article. It is determined that the modern spatial development of regions and countries is not possible without the appearing and operation of innovative structures. The role of transport routes in ensuring the sustainable economic development of district of the Carpathian region is considered, and a theory of transport corridors as a factor of economic development of the Carpathian region is proposed. The appropriate schematic map is elaborated, on the basis of which peripheral territories (sectors), which are situated outside the influence of the main traffic arteries, are singled out. Taking into consideration location and the specific socio-economic development of appropriate sectors, differentiated tasks are elaborated, which should be priority in the strategies of social and economic growth of appropriate district in terms of European integration processes intensification. In the article there is suggested to realize modelling strategic directions of the Carpathian region economy development by different scenarios that anticipate different directions and action intensity of specific groups of factors, on the grounds of summary generalization of statistical analysis methods and results of thorough investigation of economy development processes of the Carpathian region in the context of European integration of Ukraine under conditions of instability of external environment factors. Practical implications. The results can be used in the development of strategic plans for development of the Carpathian region, as well as infrastructure development with a focus on the draft spatial innovation network of Transcarpathian oblast. Value/originality. Taking into account stated view of scenarios of the Carpathian region economy development under conditions of European processes intensification, the grounding of separate statements of economy development strategy of the region and specific mechanisms of solving the urgent problems of its economic growth is considered.
\end{abstract}

Key words: Carpathian region, European integration, innovation network, spatial development, innovation infrastructure.

JEL Classification: R11, R58, F15, O32, 018

\section{Introduction}

The category of economic development of the region is treated enough in domestic science as well as in foreign one no longer includes all the aspects of operating of regional social systems in present-day conditions. Moreover, the theories of social geography and regional economy, which enlighten the problem of space in economic activity somewhat one-sided, are often clashing and incompatible. Considering it, there arise not only indispensability to solve applied decisions of spatial disposal of economic agents, but also a need of grounding the theoretical and methodological principles of spatial development of economics of the region, in economic science.

The following domestic scientists investigated the problem of development of economics of oblasts of the
Carpathian region in the context of European integration processes: Y. Holovach, M. Dolishniy, F. Zablotskyi, Y. Kish, N. Mikula, M. Lendyel, V. Khymynets etc. Yet problem of spatial development in the Carpathian region in the context of deepening of European integration processes is faintly enlightened in the domestic scientific literature.

\section{Spatial development}

Spatial development (according to I. Minyaylenko, 2013) is a form of coordination of dynamic process of quantitative and qualitative changes of any phenomena (region, economy of region, social-economic system), which takes into consideration connections of all components. As a

\footnotetext{
Corresponding author:

${ }^{1}$ Department of Accounting, Uzhgorod Trade and Economic Institute of Kyiv National Trade and Economic University.

E-mail: cenkler.knteu@gmail.com
} 
result, development acquires a new qualitative condition in a form of some correlation of elements that insures synergetic effect. Spatial development cannot be reduced to any quantitative changes or economic growth. Its content as a category is determined also by totality of factors, which have influence on life quality: life duration, condition of environment, condition of public health, purchase ability of population, quality of housing conditions, level of economic and political stability etc. It is no wonder that spatial development in many respects is tightly connected to innovative development, which has immediate influence on level of production, technologies, education, medicine, quality of life of population, environment condition.

Spatial development in our understanding is optimal combination of all components of region development (social, economic, cultural and ecological) with creation of new special structures that combine social, as well as natural components. In such interpretation, spatial development is an attempt to integrate conceptions of economic development of the region in its all-embracing meaning and conception of territorial society organization into one-entity. In other words, spatial development is spatial and time category, and includes dynamic and structural, as well as spatial components.

An optimal example of realization the conception of spatial development in regions is creation of economic clusters in wide understanding. It is worth to notice a category "development" in general, as well as a category "spatial development", can be characterized by different trends. Thus, one can speak about progressive and regressive spatial development. It is obviously that transformation of economics of the region in the context of activation of European integration processes requires properly progressive spatial development of economics of the region.

Extension of circle of factors that are taken into consideration, removal of centre of gravity from the general territorial problems to the regional level, more complete consideration of regional peculiarities and interests of population and also multi-criteria approach to evaluation of rationality of regions economy development should be emphasized among the most important directions of methodology evolution of current regional investigations. In connection with this, revision and change of theoretical and methodological principles of regional economic development takes place. This process and its result are less and less connected with concept "territory". Instead of it, attention of scientists is attracted by more capacious category "space". Spatial aspect of analysis of economic development is the most complete reflection of reality, assists deepening of knowledge on cooperation of objects, their spatial and temporal connections (Olshanska, 2011)

Furthermore, it should be pointed out that level and quality of life of population is determined not only by economic sphere, but also by possibility of national culture development, ecological safety degree, freedom of choice between some kinds of activity and preservation of traditional way of life. Owning to it, criteria of selection of regional social and economic systems also change. The most important among them are the following ones:

- increase of life level, degree of social welfare of population and other social criteria that not always have economic character;

- economic effect value for present regional system that can be expressed in a form of growth of labour and intellectual potential;

- degree of ecological safety and preservation of anthropological and natural balance of ecosystems (Olshanska, 2011).

\section{Spatial structure of economic of the Carpathian region}

Spatial structure of economic of the Carpathian region is characterized by substantial disproportions, which are even more expressed than in branch dimension. Such differences in the territorial allocation of economic activity in the region are mainly stipulated by natural and geographic premises, and by system of settling that was formed historically. Mentioned problem was analysed in detail in a line of investigations of domestic scientists.

However, in new economic conditions the most prospective and significant component of the territorial structure of economic of the region is its spatial clustering. It consists in creation and functioning of specific functional and spatial forms of economic activity organization in a shape of innovative clusters. From the point of view of crossborder cooperation and European integration processes the problem of creation of cross-border innovative clusters is worthy of special attention.

As I. Peleschak (2008) indicates, cross-border clusters create cooperation of neighbouring frontier territories of neighbouring countries. That is, availability of common border of countries between frontier territories of neighbouring countries that cooperate is determinant. They are based on using competitive advantages of neighbouring countries territories, which participants of cluster belong to.

In this context, we can also offer principle of equal weighting of cross-border development, which consists in convergence of regional social systems of neighbouring countries and is the main premise of intensification of integration processes on the intergovernmental level. Undoubtedly, mentioned principle contradicts the quite broadcast paradigm of international economic integration, which consists in neglect of regional aspects and is based on centralized decisions of state authority bodies. However, in the context of present tendencies of development of social-political and economic system of Ukraine, in particular, actualization of processes of decentralization of regional development, properly principle of equal weight of cross-border development, suggested by us, can be laid down in base of intensification of European integration processes in our country.

As it is known, since the end of XX century ideas of "green economics" were spread in economic science - ascending 
economic development of society without changes of surroundings with application of "remedial technologies" of energy as well as raw materials. Promising direction of development of these ideas is "blue economics", which foresees that logic of development of natural ecosystems, their complementarity and balance that goes beyond endurance of ordinary preservation of resources, should be laid in base of economic growth (Gunter Pauli, 2012).

Natural systems work under the principle of total transformation of raw material resources from one kind to another, which lets implement stable production that is higher degree of functioning. In concentrated form, essence of blue economics consists in consideration of integral ecological and economic effect under results evaluation of all kinds of economic activity. Integral ecologicallyeconomic effect is a non-linear sum of two different by nature effects - traditional economic and ecological. An important aspect of blue economy is priority of preventive measures concerning negative influence of manufacturing economic activity on environment.

Implementation of cluster development model into economy of mountain territories of the Carpathian region is considered an important example of efficient use of blue economy ideas. As V. Khymynets (2013) thinks, this region should be represented for investors as a region attractive for placing of manufactures with great deal to environment cleanness, availability of appropriate infrastructure and highly qualified labour resources. There are all the preconditions for clusters appearance in district of the Carpathian region. Their creation does not require large-scale financial expenditures from the state, but lays in the plane of good combination of sustainable development conception, adequate legislative support and efficient administrative decisions.

It is worth also to consider an influence of settling system of the Carpathian region on development of its economy in the light of European integration processes activation. To our point of view, under the present conditions traditional opinions on principles of productive forces placement and their role in economic development of territories gradually lose their actuality. In the reason of the space traditional role as a place, where sources and subjects of economic activity are disposed, and as its weighty factor, under conditions of computer and network technologies expansion, and innovative development activation becomes out-of-date.

\section{Spatial model of economic development of oblasts of the Carpathian region in the context of European integration}

Considering it, we can compare properly two approaches to spatial development on the example of the Carpathian region - traditional and modern one. Traditional approach pays attention to the importance of manufacturing resources disposition and goods consumers and services for projection of manufactures and other forms of territorial organization of economy. It is worth to notice that according to this approach innovative development of territories is still planning. For example, there is planning creation of network of woodworking clusters on the mountain-afforested territories of the Carpathian region. In such way, combination of traditional resource approach in regional economy with modern forms of spatial development takes place. This turns out in processes of economic clusterization.

From our point of view, a modern approach makes accent on disposition of intellectual resources inside the region, and the role of natural factors and space, on condition of information network availability, becomes secondary. Available technologic resources let organize scientific manufactures not only on the base of large industrial centres, but also in relatively peripheral regions, including mountain ones, where innovative scientific and technical activity can be successfully combined with recreation and tourism. Moreover, just favourable ecologic conditions and reach natural resources, on condition of developed infrastructure availability, can secure optimal working and resting conditions, for example, experts in IT-technologies, for professional activity of which they do not need special facilities and bulky equipment. Right intellectualization of economic activity on peripheral from standpoint of traditional approach territories, is, from our point of view, perspective approach in transformation of the Carpathian region economy accounting foreign experience, in particular European one.

From our point of view, taking into consideration the results of analysis of external economic activity of the Carpathian region and its demo-social potential, it is reasonable to elaborate a model, which should account potential of separate district of the Carpathian region, as well as their direction on activation of international integration processes.

Accounting configuration in space of the Carpathian region, optimal version of structure of such spatial model can be sector approach, which was in particular applied by U. Pavlyuk (2013), for analysis of ecologic security of Lviv. Constructed model illustrates simultaneously three indices - gross regional product (filling intensity), demographic potential, i.e. population quantity of region (width of appropriate sector) and coefficient of economy openness, calculated by us in the previous section (radius of each sector).

Received model let evaluate potential of each district of the Carpathian region concerning its possible participation in European integration processes. As we can see, despite of substantial differences of gross regional product indices and demographic potential, exactly Transcarpathian district makes significant contribution to European integration perspectives of the Carpathian region. The most unfavourable, in comparison with the others, is situation in Chernivetska district, European integration potential of which requires further development (scheme 1). 


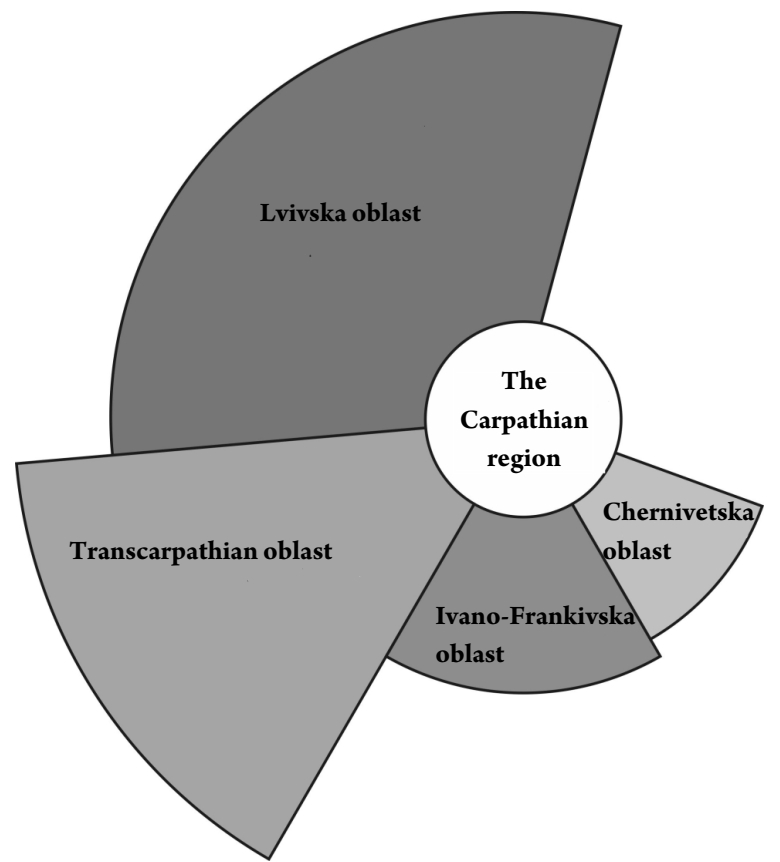

Scheme 1. Spatial model of economic development of oblasts of the Carpathian region in the context of European integration

Elaborated by authoress

However, from our point of view, it is worth to observe spatial development of the Carpathian region not only in international economic aspect, as far as adjustment of tight and efficient relations with neighbouring regions of Ukraine is also indispensable component of economy transformation of investigated region as an important component of economic system of the state. Especially perspective, from our point of view, are relations with Volyn district, which is frontier region with EU and adjusts tight economic relations with neighbouring territories of Republic of Poland. It is worth to mention in this context also Ternopilsk district, which in historical and cultural sense together with Lviv and Ivano-Frankivsk district belongs to Halychyna, thus it has important historical, cultural and social relations with mentioned regions of Ukraine.

Despite of some levelling of role of space in economic development of regions, at the present stage importance of transport infrastructure still remains quite great. The main reason of this is necessity of goods and people transfer within space, which in contrast to information transfer requires use of some kinds of transport and ways of connection. Properly development of transport infrastructure of the Carpathian region, as experts indicate, is one of its weak sides in the context of international integration processes.

On one hand, important international highways and railways pass through the territory of the region international airport of world level is operating in Lviv. On the other hand - transport ways of nationwide, regional and local importance are in improper condition and practically cannot be used efficiently under conditions of economic development of the region activation. Certainly, for the last decades, the situation with development of transport infrastructure of regions considerably improved, but mainly certain improvements in this direction were connected only with conducting the European Football Championship in the year 2012. As far as football matches were conducted in Lviv, then, first of all, development of transport infrastructure began to improve dynamically in the regional centre of Lviv district. In addition, some positive changes envelope traffic arteries of international importance, including aviation ones.

At the same time, the greater part of the territory of the Carpathian region, especially mountain one, is secured by transport ways of proper quality on unsatisfactory level. It is obviously that solving of this problem by traditional methods is impossible and efficient state financing of appropriate programs on the present stage of Ukrainian economy development also does not appear a real way of this problem solving. There exist expectations that processes of decentralization, which initiate on the regional and local level in Ukraine since the year 2015, can become a perspective way of solving the problem of transport infrastructure development in the regions of the country.

Having observed in detail the role of transport ways in providing with stable economic development of the Carpathian region, we can note that accounting specific natural conditions and resources, development of transport here largely determines possibilities of socialeconomic growth of separate territories. Thus, we can offer and prove the theory of transport corridors as a factor of economy development of the Carpathian region.

Having indicated the main traffic arteries that pass through the territory of the Carpathian region on the schematic map, in particular road of international importance Kyiv-Chop, and having drawn conventional transport corridors, which narrow in mountain locality, we can clearly notice peripheral territories or sectors, which are disposed out of the main traffic arteries influence (scheme 2).

Having analysed the indices of social-economic development of district of the Carpathian region and their internal differentiation, we can notice essential correlation between depression of economic development of territories and their distance from the main traffic arteries.

Having singled out peripheral territories to appropriate sectors, taking into consideration their disposition and specific character of social-economic development of proper regions, possibility of differentiated tasks elaboration appears, which must be priority in the strategies of social-economic growth of appropriate regions from position of European integration processes activation (table 1).

Despite of perspective importance of peripheral territories, nevertheless, the main driving forces of economy of the region transformation in the context of European integration processes activation are the large cities. High economic and intellectual potential is 
concentrated exactly in the large cities of the region. It lets not only plan but also implement the main directions of economic activity transformation in the region, taking into consideration European examples.

Afterwards, from our point of view, one of perspective directions of European integration processes intensification in the Carpathian region may be projecting of not only European regions, but also "European cities".

By analogy with European region, European city can also be considered as organizing legally consolidated form of cross-border regional cooperation between territorial communities and/or state authority bodies of frontier regions of several countries with common boundary.
At the same time, from our point of view, legal consolidation of European cities as a form of international cooperation at present stage is not obligatory. Their interpretation as intensification poles of European integration processes on the regional level and inclusion into regional strategy of development in such role seems more expedient.

In addition, in contrast to conception of European regions, European cities occupy small territory that is characterized by considerable similarity of population, as well as of economic potential. European cities administration is also considerably easier process, taking into consideration their compactness.

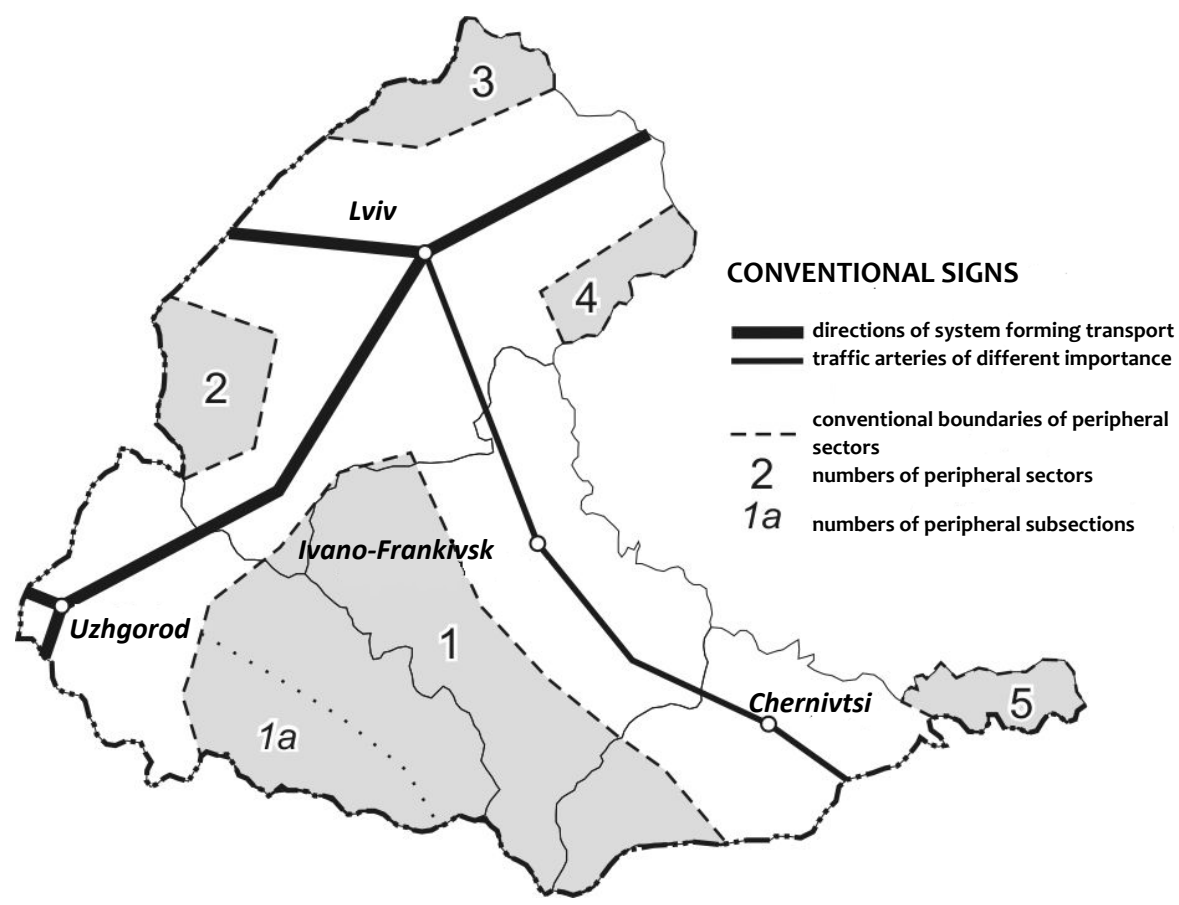

Scheme 2. Spatial structure of the Carpathian region perspective development according to the theory of transport corridors

Elaborated by authoress

Table 1

Priority tasks of spatial development of peripheral territories of the Carpathian region

\begin{tabular}{|c|l|l|}
\hline Sectors (subsections) & \multicolumn{1}{|c|}{ Oblasts } & \multicolumn{1}{c|}{ Priority tasks } \\
\hline Sector 1 & $\begin{array}{l}\text { Ivano-Frankivska, } \\
\text { Thranscarpathian, } \\
\text { Chernivetska, Lvivska }\end{array}$ & $\begin{array}{l}\text { - development of transport and tourist infrastructure; } \\
\text { - creation of international recreational clusters; }\end{array}$ \\
\hline Subsection 1a & Transcarpathian & $\begin{array}{l}\text { - development of frontier infrastructure; } \\
\text { - creation of cross-border clusters with neighbouring regions of Hungary; }\end{array}$ \\
\hline Sector 2 & Lvivska & $\begin{array}{l}\text { - development of transport and tourist infrastructure; } \\
\text { - intensification of cross-border cooperation with neighbouring regions of Poland; }\end{array}$ \\
\hline Sector 3 & Lvivska & $\begin{array}{l}\text { - creation of cross-border clusters on the base of small towns; } \\
\text { - development of frontier infrastructure; }\end{array}$ \\
\hline Sector 4 & Lvivska & $\begin{array}{l}\text { - development of transport infrastructure; } \\
\text { - increase of life quality of population; }\end{array}$ \\
\hline Sector 5 & Chernivetska & $\begin{array}{l}\text { - development of frontier infrastructure; } \\
\text { - creation of recreational clusters. }\end{array}$ \\
\hline
\end{tabular}

Elaborated by authoress 
At the same time, sustainable difference of the European city is absence for the most part common border with neighbouring countries of EU. Although, there is no doubt that taking into consideration geographical closeness of the Carpathian region to EU and developed enough international transport relations, absence of direct spatial contact of the cities of the region with EU countries does not seem development factor of special importance. At the same time, on the city level intercultural relations and interpersonal interaction are highly active. From our point of view, all this together with crossing of intensive traffic streams causes progressive influence of the European cities on European integration processes activation within the Carpathian region.

Pertinent to the European city conception can be concept of urban-cluster, which is treated, in particular by G. Komarnytska (2013) as "territorial combination of settling forms and kinds of economic activity that is a source of extension of range of social innovations, including specific urban way of life, and a generator of growth of the modern city agglomerations".

One of the real examples of the European city in the Carpathian region is Lviv. Just conducting of matches of final part of the Football Championship of Europe in Lviv in the year 2012 and increase of tourist streams in the next years assured transfer of the city to new level of socialeconomic development, its approaching to the proper European examples. Just after the year 2012 European standards in the sphere of urban construction, municipal utilities, transport etc. are actively implemented within the city. In other words, all the spheres of city administration that are in competence of local authorities suffer active reforming. It is no wonder that in the year 2015 Lviv became the second city of Ukraine, in which after Kyiv new police was introduced.

As we can see, nationwide conception of creation of economy growth poles, taking into consideration the fact that a range of economic centres has a lot of aspects and are multifunctional, despite of war actions and terrorist menaces, is in progress successfully and rapidly enough.

However, from our point of view, one city on the example of Lviv within the Carpathian region is not enough.
Undoubtedly, the most perspective in the context of transformation to the European city in our understanding is Uzhgorod, which taking into account close disposition to the borders of European Union, availability of close traditional cross-border relations, can acquire appropriate significance already in the nearest future. Similar situation is typical for Chernivtsi too. Somewhat more problematic is creation of the European city on the base of IvanoFrankivsk.

We cannot also pass by small towns of the region in this context, which can also be perspective as the poles of economic growth in the context of European processes intensification.

Undoubtedly, towns in borderland are worth of attention. From the view of spatial development of the region, they are considered peripheral ones in general; however, in the context of European integration they acquire special significance. There are some projects of frontier towns development and transformation of border infrastructure in the region, yet it is still too early to talk on their successfulness.

It is obviously that together with real introduction of decentralization in the sphere of regional administration and local self-government the processes of frontier towns and surrounding territories development suffer some intensification concerning spreading of the European integration processes in the region.

\section{Conclusions}

Thus, spatial development of the Carpathian region in the context of the European integration processes should be based on all-around evaluation of economic potential and development of its main possibilities in social and economic, transport and international spheres. Taking into consideration location and specific of social and economic development of appropriate sectors, differentiated tasks should be elaborated, which should be priority in the strategies of social and economic growth of appropriate district in terms of European integration processes intensification.

\section{References}

Minyaylenko, I.V. (2013). Spatial Development of the Region: Evolution of Modern Concepts Concerning the Essential of Category. Effective Economy. No. 11. Retrieved from: http://www.economy.nayka.com.ua9 ?op $=1 \& \mathrm{z}=2518$

Olshanska, O.V. (2011). Region as Spatial Socio-Economic System. Urgent Problems of Economy. No.117. Retrieved from: http://ir.kneu.edu.ua:8080/bitstream/2010/3731/1

Peleschak, I. (2008). Cross-Border Clusters and Cross-Border Associations as a Form of Cross-Border Cooperation. Heralds of Lviv University. Series “International Relations”. No.25. : 295-230.

Gunter Pauli, (2012). Blue Economy. 10 Years, 100 Innovations, 100 Million Working Positions. Report of Roman Club. Edition "Risk Reduction Foundation”: 320.

Khymynets, V.V. (2013). Institutional Principles of Constant Development of the Carpathian Region in the Context of Blue Economy. Constant Development of Economy. No. 3. : 161-165.

Pavlyuk, U.V. (2013). Socio-Economic Principles of Ecological Security of Large Cities Population: author's abstract from thesis of Candidate of economic science: 10-21.

Komarnytska, G.O. (2013). Urban-Clusters as an Innovative Structures of Urban Processes Regulation in the Region. Marketing and Management of Innovations. No. 1. : 247-253. 


\section{Наталия ЦЕНКЛЕР}

\section{ПРОСТРАНСТВЕННОЕ РАЗВИТИЕ КАРПАТСКОГО РЕГИОНА В КОНТЕКСТЕ ЕВРО- ИНТЕГРАЦИОННЫХ ПРОЦЕССОВ}

Аннотация. Целью данной публикации является оценка теоретической почвы и перспектив пространственного развития Карпатского региона в контексте углубления евроинтеграционных процессов. Методика. При исследовании использованы монографический метод, методы сравнения, анализа и синтеза, картографический метод. Результаты. В статье рассматривается теоретические основы и пути пространственного развития Карпатского региона в контексте евроинтеграционных процессов. Определено, что современный пространственное развитие регионов и государств невозможно без возникновения и функционирования инновационных структур. Подробно рассмотрена роль транспортных путей в обеспечении стабильного экономического развития областей Карпатского региона, и предложена теория транспортных коридоров как фактора развития экономики Карпатского региона. Разработана соответствующая картосхему, на основе которой выделено периферийные территории (сектора), которые расположены за пределами влияния основных транспортных магистралей. С учетом расположения и специфики социально-экономического развития соответствующих секторов, разработаны дифференцированные задачи, которые должны быть приоритетными в стратегиях социально-экономического роста соответствующих областей с точки зрения активизации евроинтеграционных процессов. Практическое значение. Результаты исследования могут быть использованы при разработке стратегических планов развития Карпатского региона, а также развития инфраструктуры с ориентацией на проект пространственной инновационной сети Закарпатской области. Значение/оригинальность. С учетом изложенного виденья сценариев развития экономики Карпатского региона в условиях активизации евроинтеграционных процессов, рассмотрено обоснование отдельных положений стратегии развития экономики региона и конкретных механизмов решения актуальных проблем его экономического роста. 